\title{
IMPACT OF CREDIT RISK AND CAPITAL ADEQUACY ON ISLAMIC AND CONVENTIONAL BANKING HEDGING
}

\author{
Abbokar Siddiq ${ }^{1 凶}$, Ebrahim Al-Gamal 2 (iD) \\ ${ }^{1}$ Coordinator of P.G Studies in Commerce, University College, Mangalore University, India \\ 2 Research scholar, Commerce department, University College, Mangalore University, India
}

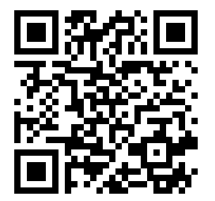

DOI: https://doi.org/10.29121/granthaalayah.v8.i10.2020.1410

Article Type: Research Article

Article Citation: Abbokar Siddiq, and Ebrahim Al-Gamal. (2020).

IMPACT OF CREDIT RISK AND

CAPITAL ADEQUACY ON ISLAMIC

AND CONVENTIONAL BANKING

HEDGING. International Journal of

Research -GRANTHAALAYAH,

8(10), 198-206.

https://doi.org/10.29121/granthaa

layah.v8.i10.2020.1410

Received Date: 06 September 2020

Accepted Date: 31 October 2020

Keywords:

Credit Risk

Capital Adequacy

Baking Hedging

Yemen

\section{ABSTRACT}

This study aims to examine the relationship between credit risk and capital adequacy with the banking hedging of Islamic and conventional banks in Yemen. A sample of 4 conventional banks and 3 Islamic banks was used during (2012-2017). Using Pearson correlation and regression analysis, the study concludes that there is a statistically significant relationship between credit risk and banking hedging and a strong statistically significant relationship between capital adequacy and banking hedging. Based on the type of bank, results indicate a negative relationship but no statistical significance between conventional banks' credit risk and banking hedging. There is a statistically significant relationship between credit risk and banking hedging of Islamic banks. Capital adequacy positively interacts with the banking hedging in both banks.

\section{INTRODUCTION}

Yemen, among Middle East countries, is considered the weakest country in terms of growth and development. The Yemeni banking sector is the lowest system compared to Middle Eastern countries because of the successive crises that have affected Yemen. However, dominant over the financial system, any failure in the banking sector will impact the entire economic sector of a country (Al mekhlafi et al., 2016). The Yemeni banking sector has faced many crises. The bankruptcy of the National bank in 2004 due to poor management and the inability to recover depositors 'money is one of the worst crises in the banking sector. Many challenges hindered the Yemeni banking sector's improvement, such as the large size of non-performing loans and the weak implementation of regulatory standards. However, the Yemeni financial and banking sector evolved in the last decade. This development accompanied by a set of reforms undertaken by the Central Bank of Yemen to raise the level of the banking sector in several areas including organizational, supervisory, liquidity, and credit risk management, as well as enhancing capital adequacy requirements at the beginning of 2004 (Shawtari et al., 2015). Given this improvement of the Yemeni banking sector, this improvement accompanied by an increase in growth and development of several Yemeni banks, whether conventional or Islamic banks, as well as diversity and branching of their banking activities, which led to a rise in the

(C) 2020 The Author(s). This is an open access article distributed under the terms of the Creative Commons Attribution License, which permits unrestricted use, distribution, and reproduction in any medium, provided the original author and source are credited. 
risks facing banks and impeded the fulfillment of their obligations. Bearing to the mind that Yemeni banks operate in an environment that lacks the controls that drive litigation procedures and enable banks to recover their nonperforming funds with others. For this reason, the possibility of risks accrue is high.

In light of the continuous changes in the economic environment, banks face many risks, which the most critical risks are credit risk and capital risk. International Basel committee concentrates on credit risk and capital risk because the losses that belong to both risks will cross beyond the bank to impact the country's economic and financial system, therefore to the global economy. Credit risk is the most crucial component of banking risk as a whole, contributing to more than $50 \%$ of the bank's total banking risk. Credit risk arises from the possibility that a borrower will not meet its obligations on time, which will affect the bank's income and capital (Lukic, 2015). Also, given that banks operate in a volatile environment that may expose them to risk, capital plays a significant role in helping banks to face any unexpected losses. It also represents the most crucial element in the stability, safety, and security of banks.

Islamic banks differ from conventional banks in the possibility of exposure to risks due to their business's different nature and diversity. Kabir and Worthington (2015) Indicated that according to the principles of Islamic Sharia under which Islamic banks operate, that indicates for sharing risks during loss occurs, some Islamic financial products expose them to additional credit risk. Most studies also believe that conventional banks have less credit risk than Islamic banks (Chong and Liu, 2009). However, some reviews refer that the conventional banks are more exposed to credit risk than Islamic banks, where (How et al., 2005) argue that if there is a chance of losses, Islamic banks have the option to share failures with depositors, while conventional banks do not have the same opportunity. Even capital adequacy is not less significant than credit risk because it is considered an essential defense line to Islamic and conventional banks (Karim et al. 2014). (Pellegrina, 2007) Believes that the minimum capital adequacy is inappropriate in Islamic banks because the profit-loss sharing contract reduces the overall risk of investment faced by the bank. (Chowdhury, 2011), (Smolo, 2011) Add up to that capital adequacy is a source of safety for Islamic banks, due to the nature of the risks faced by their banking products and the kind of Islamic banks as a mediator.

Moreover, many of the current studies focused on analyzing and examining the financial risks facing banks in such a way to support the hedging level of the banks. Given the importance of credit risk and capital adequacy as an indicator to maintain a hedging level, the International Settlements bank indicated that banks should define credit and capital risks accurately and measure them correctly. Considering that studies on Islamic Banking hedging and their comparison with Conventional Banks are few, it is crucial to study credit risks and capital adequacy and compare their impact on Islamic and Conventional Banks' Banking hedging. Therefore, this paper aims to determine the effect of credit risk and capital adequacy on Banking hedging of Islamic and Conventional Banks and set recommendations that help raise the level of Banking hedging. The current study focuses on Yemen, considering that Yemeni Banks suffer from profound imbalances in their credit policies and capital adequacy and suffer from deficiencies in keeping pace with technical and technological developments. This study, as far as we know, is considered the first in Yemen that compares the impact of credit risks and capital adequacy on the Banking hedging of Yemeni Islamic and Conventional Banks.

The remainder of this paper was organized into the following: 2 Framework and Review of Literature, 3 Data and Methodology, 4 Result and Discussion, 5 Conclusion.

\section{FRAMEWORK AND REVIEW OF LITERATURE}

The rapid development of banking transactions and its functions, the big trend towards the open economy, weak regulations and legislation related to the banking business, the weakness of qualified cadres, and other factors led to increasing the risk face banks such as credit risk, capital adequacy risk, liquidity risk, interest rate risk, and operational risks. These risks may affect banks' performance, profitability, and security, which led many researchers to study the risks and their impact on banks from several different dimensions, whether performance, profitability, or hedging. Accordingly, credit risk among all the types of risks consider as the critical risks that face banks and financial intermediaries (Gray et al., 1997). Also, capital adequacy is highly significant and protects the bank from financing leverage and keeps banks away from the difficulties caused by insolvency and risk aversion (Nikhat,2014). Therefore, as a result, these risks may impact banking hedging, that consider as the precautions and caution against the risks that commercial banks are exposed to from their operational operations (Hempel, 1999), either directly or 
indirectly. Thus, several empirical studies contribute to our prior understanding of credit risk and capital adequacy and their effect on Banking hedging.

Credit is important for individuals and nations, and as the banks are the main center for granting credit, it creates a significant risk for the banks (Al-Gamal \& Siddiq, 2019). Therefore, several studies have compared the credit risk of conventional and Islamic banks in recent years by statistical-based techniques. To start, Kabir et al. (2015) evaluated the levels of credit risk in 37 Islamic and 156 conventional banks across 13 countries by using a market- based credit risk measure, and their result has shown that Islamic banks have significantly lower credit risk than conventional banks. They argue that the method used for measuring credit risk plays an essential role in the level of measured credit risk. Nevertheless, Mongi (2018) argues that the Islamic banks had significantly higher credit risk than the conventional banks when he applied country-level data of 17 Islamic banks and 22 conventional banks in Malaysia based on generalized least squares (GLS). Furthermore, credit risk considers the most significant risk faced by banks. The success of the bank's functions depends on accurate measurement and efficient management of this risk. Aezzki (2012) reported the reverse influence of credit risk on the profitability of the Yemeni commercial banks at each bank or the banks' level collectively. Subsequently (Almekhlafi et al., 2016) used credit risk, bank performance measures 3and macroeconomic indicators to examine the interaction between credit risk and Banks performance in Yemen, and they emphasize that non-performing loans shown a negative relationship with Banks profitability and performance and the high loan recovery cost associated to high credit risk exposure.

On the other hand, capital plays a prominent role in facing potential risks in the event of insufficient allocations and reserves, and this is the reason that prompted the Central banks to raise the banks 'capital to provide an adequate margin of safety for depositors and stakeholders (Saunders and Cornett, 2002). Several studies discussed capital adequacy as (Berger, 1995), (Altamimi and Obeidat, 2013), (Bokhari et al., 2013), (Rina and Yovin 2016), (Yuanjuan and Shishun, 2012).

Berge (1995) examined the relationship between profitability and capital in American commercial banks by using regression analysis to analyze two periods (1983-1989) and (1990-1992) due to some changes in laws and regulations related to commercial banks in American during these two periods. The result indicates a strong positive relationship between profitability and capital during the first period when the capital was below the optimal level and an inverse relationship between profitability and capital when the capital was higher than the optimal level. Later (Yuanjuan and Shishun, 2012) measured the factors of capital adequacy in Chinese banks. They found that the return on assets positively proportional to the capital adequacy, and the liquidity and quality of assets are inversely proportional to the capital adequacy. Moreover, when (Bokhari et al., 2013) apply the same analytical method to Pakistani banks, reported that return on equity, deposits, and portfolio risks is inversely proportional to the capital adequacy, while the rest of the variables did not show any effect with the capital adequacy. Also (Altamimi and Obeidat, 2013) investigate the factors that determine the degree of capital adequacy in Jordanian commercial banks and conclude that there was no correlation between capital adequacy with capital risk and credit risk. Subsequent (Rina and Yovin 2016) concluded that capital risks affect private banks' performance, while credit risks affect the performance of the government banks by examining the impact of capital adequacy and additional factors on return on assets in government and private banks in Indonesia.

Furthermore, banking hedging studies linked to several dimensions that most important of these were liquidity risks, investment risks, capital risks, credit risk, interest rate risk, in addition to independent variables related to the rate of return on equity and the rate of return of investment. Kharawish et al. (2004) researched the factors that affect the level of banking hedging in 13 selected Jordanians banks by used a financial analysis ratio based on multiple regression and reported that credit risk showed an Inverse relationship with banking hedging; furthermore, return on equity and return on assets showed a positive relationship with banking hedging. Besides, Al ajlouni \& alrgabat ( 2014) emphasize that credit risk is the highest risk that impacts the banking hedging due to the late payment of the loan and interest. Nevertheless, (Omran 2015) argues that capital risk is the most risk that impacts banking hedging, and credit risk did not affect the degree of banking hedging in Syria. Nevertheless, subsequent, Alafeef \& al-Taani (2017), based on the model developed by (aljoluni \& alrgaib,2004) found that there is an inverse relationship between credit risk and the degree of banking hedging with no significant effect due to the irregularity of the criteria for the calculation of bad doubtful debts during the period of the study. , Furthermore, (Amran 2015) and (Sabah \& shaheen, 2008) used the financial analysis ratio based on regression analysis to examine the relationship between banking hedging and risks and reported a negative relationship between credit risk and banking hedging. Nevertheless (Alameen et al., 2014) argue that while banking hedging positively interacts with capital risk, it does not show any interaction with credit risk; it also indicates that capital adequacy has a positive 
Impact of Credit Risk and Capital Adequacy on Islamic and Conventional Banking Hedging

relationship with capital risk and a negative relationship with credit risk. In an extension related to the current literature (khuyukah \& Abdulrahman,2014) used data of Islamic banks to build a measurement model to describe the degree of banking hedging by evaluating and analyzing the banking statement's indicators and their impact on banking hedging. The results support the idea of most of the previous studies that symbol the inverse relationship between credit risk and banking hedging and the positive correlation between capital adequacy and Banking hedging.

According to the result of the previous studies on the effect of credit and capital adequacy on banking, hedging is still under debate, and the obtained results are diverging. In this respect, despite the existence of previous studies, we believe this study is an addition to the earlier studies because it includes investigating of the extent of influence and relationship between two groups of the dependent variable (banking hedging) and independent variables (credit risk and capital adequacy) and the lack of studies that concern about the Islamic Banks and its comparison with the Conventional Banks in Banking hedging issue. So that a model will be specified to measure the degree of Banking hedging in Yemeni Islamic and Commercial Banks, Therefore, based on the foretasted theoretical developments to test the hypothesis that formulated as below:

H1. There is a no statistically significant relationship between credit risk and Banking hedging.

H2. There is a no statistically significant relationship between capital adequacy and Banking hedging.

\section{DATA AND METHODOLOGY}

This This paper is limited to a homogeneous sample that includes conventional banks and Islamic banks' coverage in Yemen. Among 17 banks in Yemen, only seven banks were chosen and included four conventional banks and three Islamic banks during a period (2012-2017), known as the biggest banks and represent more than 60\% of the Yemeni banking sector. Through the uses of banks' databases to analyze the annual reports, which almost was entirely available for the specific period, this duration represents the period that Yemeni banks faced political and economic issues, which obliged the banks to work better to increase banking hedging. Data were collected from CAC Bank, International Bank of Yemen, Yemeni Bank for Reconstruction and Development, Yemeni National Bank, Saba Islamic Bank, Bank of Yemen, and Bahrain Shamil, Tahdamon International Islamic Bank.

However, this study's main objectives are to examine the effect of credit and capital risk on banking hedging, where the theoretical framework for the study was developed based on previous reviews and books related to the study. In the practical aspect, the descriptive and analytical method used to describe, analyze and interpret the results to achieve the objectives of the study, which relied on the analysis of financial reports related to the study variables, where the particular financial ratios were calculated for independent and dependent changes for each bank separately. Statistical methods were applied to achieve the study's objectives and test the validity of its hypotheses, such as the arithmetic mean standard deviation and simple linear regression using the statistical package (SPSS).

Banking Hedging $=$ Shareholders $/$ Total assets or risky assets (1)

Credit Risk = Risky assets / Total assets (2) (Kharawish et al., 2004)

Capital Adequacy = Primary capital / Risky assets (3)

Risky Assets = long term loans + long term investment. (4) (Madura,2001).

Furthermore, the model was built on the descriptive model, that was adopted by many researchers in clarifying the relation between the variables, therefore, the model to be tested is:

$\mathrm{BH}=\alpha 0+\beta 1 * \mathrm{CR}+\beta 2 * \mathrm{CA}++\varepsilon \dot{\mathrm{i}}(5)$

Whereas:

BH: Banking Hedging ～， CR: Credit Risk. ～，CA: Capital adequacy 


\section{RESULT AND DISCUSSION}

\subsection{RESULT}

Table (1.1) displays descriptive statistics for the dependent variable and independent variables. It shows that the minimum value for the dependent variable represented by banking hedging was (.038) while the maximum value (.153) and the mean were (.09136) with a standard deviation equal to (.032079). For independence variables, the minimum value for the credit risk and capital adequacy was (.050) (.075) while the maximum value (.799) (.830), and the mean was (.31278) (.36185), with a standard deviation equal to (250944) (.198122), respectively.

Table 1.1: Descriptive Statistics

\begin{tabular}{|c|c|c|c|c|c|c|c|c|c|c|c|c|c|}
\hline & \multirow{2}{*}{$\mathrm{N}$} & \multicolumn{3}{|c|}{ Minimum } & \multicolumn{3}{c|}{ Maximum } & \multicolumn{4}{c|}{ Mean } & \multicolumn{3}{c|}{ Std. Deviation } \\
\cline { 3 - 15 } & & con & isl & All & con & isl & all & con & isl & all & con & isl & all \\
\hline B.H & 42 & .038 & .047 & .038 & .132 & .153 & .153 & .0843 & .1008 & .0914 & .0271 & .0364 & .0321 \\
\hline C.R & 42 & .050 & .375 & .050 & .180 & .799 & .799 & .1096 & .5837 & .31278 & .0403 & .1168 & .2510 \\
\hline C.A & 42 & .210 & .075 & .075 & .830 & .348 & .830 & .4893 & .1919 & .36185 & .1550 & .0931 & .1981 \\
\hline \multicolumn{2}{|c|}{$\mathrm{N}$} & 24 & 18 & 42 & 24 & 18 & 42 & 24 & 18 & 42 & 24 & 18 & 42 \\
\hline
\end{tabular}

To begin analyzing the relationship of credit risk and capital adequacy with the banking hedging of Islamic and conventional banks, the Pearson correlation and linear regression to be used in this part of the analysis. It can be clear from Table (1.2) that credit risk is weakly proportional to the banking hedging at a significant statistics level of (.087), and capital adequacy strongly proportional to the banking hedging at the level of significance (.638).

Based on the type of bank, there is a significant difference in credit risk and capital adequacy with the banking hedging between Islamic and conventional banks. We reported an inverse relationship between the credit risk and banking hedging of conventional banks at the significance (.842). Capital adequacy showed a related relationship with the banking hedging at the level of significance (.254). While Islamic banks showed that credit risk is directly related to banking hedging at the level of significance (.627), and capital adequacy showed a strong and positive relationship with the Banking hedging at the level of significance (.000).

Table 1.2: Pearson Correlation

\begin{tabular}{|c|c|c|c|c|c|c|c|c|c|c|}
\hline \multicolumn{2}{|c|}{} & \multicolumn{3}{c|}{ Conventional } & \multicolumn{3}{c|}{ Islamic } & \multicolumn{3}{c|}{ All } \\
\cline { 3 - 11 } \multicolumn{2}{|c|}{} & B.H & C.R & C.A & B.H & C.R & C.A & B.H & C.R & C.A \\
\hline B.H & Pearson Correlation & 1 & & & 1 & & & 1 & & \\
& Sig. (2-tailed) & & & & & & & & & \\
& $\mathrm{N}$ & & & & & & & & & \\
\hline \multirow{4}{*}{ C.R } & Pearson Correlation & $-.043-$ & 1 & & .123 & 1 & & .267 & 1 & \\
& Sig. (2-tailed) & .842 & & & .627 & & & .087 & & \\
& $\mathrm{~N}$ & 24 & & & 18 & & & 42 & & \\
\hline C.A & Pearson Correlation & .242 & $-.794-$ & 1 & $.808^{* *}$ & $-.048-$ & 1 & .075 & $-.772-$ & 1 \\
& Sig. (2-tailed) & .254 & .000 & & .000 & .849 & & .638 & .000 & \\
& $\mathrm{~N}$ & 24 & 24 & & 18 & 18 & & 42 & 42 & \\
\hline
\end{tabular}

It is clear from Table (1.3) that the value of the determining factor (R square) of the model is (.267), and it is considered a reasonably good value and indicates that the explanatory strength of the model is good. It is showed that (\%26.7) of the changes in the dependent variable (banking hedging) are due to changes in Independent variables (credit risk, capital adequacy) and that (\%73.3) of the changes in banking hedging of Yemeni banks is due to factors and other variables not included in the study.

The errors are estimated (.028160), which is a small value and refers to the model's predictive ability.

This reasonably good indication of the model variables explains that although Yemeni Islamic banks have achieved an excellent value for the factor (R square) of the model by (.680), which demonstrates (\%68) of the changes in the dependent variable (banking hedging) in Islamic banks due to changes in independent variables (credit risk, capital adequacy). Also, only (\%32) from changes in the degree of banking hedging in Islamic banks due 
to other factors and variables not included in the model, and errors estimated (.021918). However, it is noted that in conventional banks, the determination factor (R Square) equal to (.119), which indicates that only (\%11.9) of the changes in (banking hedging) in the conventional banks are due to changes in independent variables (credit risk and capital adequacy) and that the percentage (\%88.1) is expected to changes in factors and variables not included in the study, also, the estimated errors (.026619).

Table 1.3: Model Summary

\begin{tabular}{|c|c|c|c|c|}
\hline Model & $\mathrm{R}$ & R Square & Adjusted R Square & Std. Error of the Estimate \\
\hline 1 & $.517 \mathrm{a}$ & .267 & .229 & .028160 \\
\hline
\end{tabular}

a. Predictors: (Constant), Capital Adequacy, Credit Risk

Table (1.4) shows ANOVA analysis of study variables, where the value of the coefficient $(\mathrm{f}=7.103)$ is considered reasonably good, and its degree of significant (sig=.002) is less than (0.05), which indicates the significance of the Fischer coefficient to test the importance of the model.

Based on the type of bank, there is a significant difference in regression analysis between Islamic and conventional banks. Nevertheless, Islamic banks are found that the value of the coefficient $(\mathrm{f}=15.925)$ and its degree of significance ( $\mathrm{sig}=.000$ ) is less than $(0.05)$. In contrast, conventional banks are found that the value of the coefficient $(\mathrm{f}=1.418$ ) and its degree of significance $(\operatorname{sig}=.265)$ is more than $(0.05)$.

Table 1.4: ANOVA

\begin{tabular}{|c|c|c|c|c|c|}
\hline Model & Sum of Squares & $\mathrm{df}$ & Mean Square & $\mathrm{F}$ & Sig. \\
\hline Regression & .011 & 2 & .006 & 7.103 & $.002^{\mathrm{b}}$ \\
Residual & .031 & 39 & .001 & & \\
Total & .042 & 41 & & & \\
\hline
\end{tabular}

a. Dependent Variable: Banking Hedging

b. Predictors: (Constant), Capital Adequacy, Credit Risk

Table (1.5) shows the regression coefficients of the model variables (credit risk and capital adequacy risk). Results showed that the coefficient $t$ of credit risk is (3.729) at a significant level $(\operatorname{sig}=.001)$, which is smaller than $(5 \%)$. However, regarding the measure of the coefficient of capital adequacy $(t=3.729)$ at the level of significance (.003), which is smaller than (5\%).

Table (1.5) notes the beta coefficient of the independent variables, which shows the value of the change that occurs in the dependent variable (banking hedging) as a percentage at each difference in the independent variables that affect the dependent variable. Therefore, the beta coefficient shows that credit risk and capital adequacy impact on banking hedging, but credit risk has a more significant effect, and its beta coefficient value (.804) that explains the degree of banking hedging may change by (\%80) when credit risk changes by $(1 \%)$.

Based on the type of bank, there is a significant difference for coefficients analysis between Islamic and conventional banks. Nevertheless, the coefficient t of the credit risk of Islamic Banks is (1.111) at a significant level $(\mathrm{sig}=.284)$, which is more than (5\%), and the coefficient $t$ of capital adequacy (5.580) at a significant level (sig = $.000)$, which is less than (5\%). While the coefficient t of the credit risk of conventional banks is (1.199) at a significant level (sig $=.244)$, which is more than (5\%), and the coefficient t of capital adequacy (1.671) at a significant level (sig $=.110)$, which is more than (5\%).

Table 5: Coefficients

\begin{tabular}{|c|c|c|c|c|c|}
\hline Model & \multicolumn{2}{|c|}{ Unstandardized Coefficients } & Standardized Coefficients & $\mathrm{t}$ & Sig. \\
\hline & $\mathrm{B}$ & Std. Error & Beta & & \\
\hline (Constant) & .018 & .021 & & .899 & .374 \\
\hline Credit Risk & .103 & .028 & .804 & 3.729 & .001 \\
\hline Capital Adequacy & .113 & .035 & .696 & 3.226 & .003 \\
\hline
\end{tabular}

a. Dependent Variable: Banking Hedging 
Abbokar Siddiq, and Ebrahim Al-Gamal

\section{DISCUSSION}

According to Pearson, correlation credit risk is weakly proportional to the banking hedging and capital adequacy strongly proportional to the banking hedging, indicating that Yemeni banks are working to maintain capital more than what was recommended by the Basel Committee for capital adequacy. Furthermore, conventional banks showed an inverse relationship between credit risk and banking hedging, which indicate that conventional Yemeni banks did not expand in granting credit due to the reluctance of most conventional banks to invest in treasury bills of monetary nature, and this result consistent with the findings of Al-Afeef \& Al-Taani (2017). Also, capital adequacy showed a related relationship with the banking hedging. While Islamic banks showed that credit risk is directly related to banking hedging, and capital adequacy showed a strong and positive relationship with the banking hedging.

The determination factor (R Square) of the Yemeni banks reasonably value and indicates that the model's explanatory strength is good. The errors estimated are small value and refer to the predictive ability of the model. Yemeni Islamic banks showed an excellent value for the factor (R square) of the model. It is clear from the results of the strong relationship between credit risk and capital adequacy with banking hedging and errors estimated is small value and indicates the predictive ability of the model. The determination factor (R Square) of conventional banks is good but weak value, and the estimated errors are small value and indicate the model's predictive ability.

ANOVA analysis indicates the significance of the Fischer coefficient to test the significance of the model, and this means that the model has a statistical significance and gives a reasonably good degree of expectation and prediction of changes in the dependent variable (banking hedging) depending on the changes in the independent variables. Based on the type of bank, there is a significant difference in regression analysis between Islamic and conventional banks. Nevertheless, the Islamic banks coefficient is considered strong, and its degree of significance is good, while the conventional banks coefficient is considered week, and its degree of relevance is week. Therefore, we reported a statistical significance in Islamic banks, and there is no statistical significance in conventional banks.

The regression coefficients show that credit risk is significant, and we reject the hypothesis that there is a relationship between credit risk and banking hedging. Also, capital adequacy is significant, and we reject the hypothesis that there is a relationship between capital adequacy and banking hedging. Based on the type of bank, Islamic banks' credit risk is shown not significant, and capital adequacy is significant. In contrast, conventional banks' credit risk is shown not meaningful, and capital adequacy is not significant.

\section{CONCLUSION}

In this paper, the impact of credit risk and capital adequacy on banking hedging of Islamic and conventional banks investigated. A sample of 7 Banks - four conventional and three Islamic - across the Yemeni banking sector for 2012- 2017. The descriptive and analytical method used to describe and analyze the results to achieve the study's objectives through the analysis of financial reports related to the study variables, Where the particular financial ratios were calculated for independent and dependent changes for each bank separately and applied the accurate statistical methods. The result showed a statistically significant relationship between credit risk and banking hedging and a strong and statistically significant relationship between capital adequacy and banking hedging. Based on the type of bank, results show a negative relationship but not statistical significance between the credit risk and Banking hedging of the conventional banks. There is a statistically significant relationship between credit risk and banking hedging of Islamic banks. Also, capital adequacy positively interacts with the banking hedging in both banks. Moreover, the results indicate that the Yemeni banking sector is still emerging, and conventional and Islamic banks have different views of risk. However, conventional banks do not grant credit significantly; Islamic banks provide credit more through many credit products. It is also clear that Islamic banks maintain capital adequacy, but conventional banks maintain a high enough capital adequacy ratio. Consequently, the results of the study are essential for Policymakers, Academics, and Bankers. Despite the limitations of this research and the lack of data, several recommendations were identified. Conventional banks should increase lending and not focus only on quasimonetary and government securities; banks need to follow the continuous development of regulatory and banking controls of risk management, Banking safety. Besides, a balance should appear between bank hedging with credit risk and capital adequacy risks. 
Impact of Credit Risk and Capital Adequacy on Islamic and Conventional Banking Hedging

\section{SOURCES OF FUNDING}

This research received no specific grant from any funding agency in the public, commercial, or not-for-profit sectors.

\section{CONFLICT OF INTEREST}

The author have declared that no competing interests exist.

\section{ACKNOWLEDGMENT}

None.

\section{REFERENCES}

[1] Abdualrahman, Tania Qadir \& Khayoka, Amer Fadel. (2014). Evaluating and analyzing risk indicators of financial bank statements and their impact on banking safety using time series models with cross sections (an analytical study on a sample of selected Islamic banks), The Journal of Administration \& Economics, University of Kirkuk, No. 99.

[2] Aezzki, Zaid. (2010). Impact of risks on Yemeni commercial banks during the period (1999-2008), Unpublished MA Thesis, University of the House, Mafraq, Jordan.

[3] Al Ajlouni, Mohannad Mohammed \& Alrgaibat, Ghazi Abdul Majeed. (2014). Impact of Risk on the Degree of Banking Safety in Traditional Jordanian Banks (2000-2011), Global Journal of Management and Business Research: C Finance Volume 14 Issue 3 Version 1.0, Type: Double Blind Peer Reviewed International Research Journal Publisher: Global Journals Inc. (USA) Online ISSN: 2249-4588 \& Print ISSN: 0975-5853

[4] Al-Afeef, Mohammad Abdel Mohsen \& Al-Ta'ani, Atallah Hassan. (2017). The Effect of Risks on Banking Safety: Applied Study on Jordanian Traditional Banks (2005-2016), International Journal of Economics and Finance; Vol. 9, No. 9; ISSN 1916-971X E-ISSN 1916-9728 Published by Canadian Center of Science and Education.

[5] Al-Gamal, Ebrahim. \& Siddiq, Abbokar. (2019). Significant of credit risk management in banking industry in yemen: A study, international journal of commerce and management research, ISSN: 2455-1627, vol: 5,, P.p 163-165 , DOI: http://www.managejournal.com/archives/2019/vol5/issue3/5-3-48

[6] Alameen, Maher \& Albahloul, Mohammad. (2014). Determinants of Capital Adequacy and their Impact on Banking Hedging: An Applied Study of Syrian Private Banks, Tishreen University Journal for Research and Scientific Studies -Economic and Legal Sciences Series Vol. (36) No. (1).

[7] Almekhlafi, Ebrahim, Almekhlafi, Khalil, Kargbo, Mohamed \& Xiangpei Hu,. (2016). A Study of Credit Risk and Commercial Banks' Performance in Yemen: Panel Evidence, Journal of Management Policies and Practices June 2016, Vol. 4, No. 1, Pp. 57-69 ISSN: 2333-6048 (Print), 2333-6056.

[8] Altamimi, M. K. A.; Obeidat, F. S. (2013). Determinants of Capital Adequacy in Commercial Banks of Jordan An Empirical Study, International Journal of Academic Research in Economics and Management Science, Pakistan, Vol. 2. No. 4, 44-58.

[9] Amran, Abdul Wahid Saeed. (2005). The effect of risk management (liquidity - credit - capital) on the degree of banking safety, an applied study on the National Commercial Bank, No. 3, Department of Finance and Banking - College of Economics - Omar Al-Mukhtar University.

[10] Berger, A. N. (1995). The relationship between capital and earnings in banking. Journal of Money, Credit and Banking, 432-456.

[11] Bokhari, H. I.; Ali, M. S.; Sultan, K. (2013). Determinants of Capital Adequacy Ratio in Banking Sector an Empirical Analysis from Pakistan, Academy of Contemporary Research Journal, Pakistan, Vol. 2. No. 1, 1-9.

[12] Chong, B., Liu, M., (2009). Islam Bank: Interest-Free or Interest-Based? Pac-Basin Financ. J. 17, 125-144.

[13] Chowdhury, M. (2011). An introduction to banking, John Wiley \& Sons, International Journal of Business and Finance Research, Vol. 10.

[14] Gray, B., Cassidy, C., \& RBA (1997). Credit Risk in Banking: Proceedings of A Conference At H.C. Coombs Centre For Financial Studies, 1-2 May 1997. [Melbourne]: Reserve Bank of Australia, Bank Supervision Department. 
[15] Hemple, D. (1999). Bank Management: Text and Cases (5th ed.), N.Y.: John Wiley and Sons, Inc.

[16] Kharwsh, H., Al-Zubi, K., \& Al- Abadi, M. (2004). Factors Affecting the Degree of Banking Safety in Jordan. Journal: Economics and Management, King Abdulaziz University, 2(18), 59-77. Retrieved from http://www.kau.edu.sa/Files/320/Researches/51705_21840.pdf

[17] Lukic, Aleksandar. (2015). Types of Risks and Risk Management in the Contemporary Banking Operations, International Journal of Advanced Research, Vol 3, No 3.

[18] Md. Nurul Kabir, Andrew Worthington \& Rakesh Gupta. (2015). Comparative Credit Risk in Islamic And Conventional Bank, Pacific-Basin Finance Journal 34, 327-353.

[19] Mongi L,. (2018). Comparative study on Credit Risk in Islamic Banking Institutions: The Case of Malaysia, Quarterly Review of Economics and Finance, https://doi.org/10.1016/j.qref.2018.05.009

[20] Nikhat Fatima (2014). Capital Adequacy: A Financial Soundness Indicator for Banks, Global Journal of Finance and Management, Volume 6, Number 8 (2014), pp. 771-776.

[21] Omran (2015). The Effect of the banking risks in the degree of banking security in the commercial banks operating in Syria "Proposed Model", Tishreen University Journal for Research and Scientific Studies Economic and Legal Sciences Series Vol. (73) No. (1) 5112.

[22] Pellegrina Dalla, L., (2007). Capital Adequacy Ratios, Efficiency and Governance: A comparison between Islamic and Western Banks, Working Paper University of Milan-Bicocca, Department of Statistics.

[23] Rina, A.K - Yovin. (2016). Factors Affecting Bank Performance: Cases of Top 10 Biggest Government and Private Banks in Indonesia in 2004- 13, Review of Integrative Business and Economics Research, 5(4), pp. 371-378.

[24] Sabah, Bahia Mosbah \& Shaheen, Ali Abdullah. (2008). The Impact of Risk Management on The Degree of Security in The Palestinian banking sector, Master thesis, Commerce College Islamic University -Gaz.

[25] Shawtari, Fekri Ali, Shaikh, Mohamed Ariff, Razak, Hamzah Abdul. (2015). Efficiency assessment of banking sector in Yemen using data envelopment window analysis, Benchmarking: An International Journal, Vol. 22 Iss 6 pp. 1115 - 1140.

[26] Smolo, E., Hassan, M.K., (2010). Capital adequacy requirements for Islamic financial institutions. Islamic Finance: Instruments and Markets Bloomsbury Press, London, UK.

[27] Yunjuan, L.; Shishun, X. (2012). Effectiveness of China's Commercial Banks' Capital Adequacy Ratio Regulation a Case Study of the Listed Banks, Interdisciplinary Journal of contemporary Research in Business, UK, Vol. 4. No. 1, 58-68. 